\title{
Topic drug therapy for neuropathic pain
}

\author{
Farmacoterapia tópica da dor neuropática \\ Durval Campos Kraychete ${ }^{1}$, Mariana Camargo Palladini², Anita Perpétua Carvalho Rocha Castro ${ }^{3}$
}

DOI 10.5935/1806-0013.20160058

\section{ABSTRACT}

BACKGROUND AND OBJECTIVES: First line drugs indicated to treat neuropathic pain are few and their use may be limited by the presence of side effects, impairing adherence to treatment. This review aimed at evaluating whether available topic analgesics have clinical efficacy and whether they might be used as alternative or adjuvant to treat neuropathic pain.

CONTENTS: The topic effect of NSAIDs, tricyclic antidepressants, capsaicin, ketamine, clonidine and local anesthetics to treat neuropathic pain of different etiologies was evaluated.

CONCLUSION: Few studies in the literature validate the use of topic analgesics to treat neuropathic pain. On the other hand, topic 5\% lidocaine may be safely used with good analgesic effect and tolerability. The clinical efficacy of topic analgesics may be associated to the choice of the vehicle, to agent concentration, to pain location and to the specific disease.

Keywords: Analgesics, Neuropathic pain, Topic, Treatment.

\section{RESUMO}

JUSTIFICATIVA E OBJETIVOS: Os fármacos disponíveis e indicados como primeira linha de tratamento da dor neuropática são poucos e o emprego desses agentes pode ser limitado pela presença de efeitos adversos, prejudicando a aderência ao tratamento. $\mathrm{O}$ objetivo desta revisão foi avaliar se aos analgésicos tópicos disponíveis para uso apresentam eficácia clinica e se podem ser utilizados como alternativa ou como adjuvante no tratamento da dor neuropática.

CONTEÚDO: Foi avaliado o efeito tópico dos anti-inflamatórios não hormonais, os antidepressivos tricíclicos, a capsaicina, a cetamina, a clonidina e os anestésicos locais no tratamento da dor neuropática de diversas etiologias.

CONCLUSÁO: Poucos estudos da literatura validam o emprego de analgésicos tópicos no tratamento da dor neuropática. Por outro lado, a lidocaína tópica a $5 \%$ pode ser utilizada de forma segura, com bom efeito analgésico e tolerabilidade. A eficácia clinica dos analgésicos tópicos pode estar associada a escolha do veículo, a concentração do agente, o local da dor e a doença específica

Descritores: Analgésicos, Dor neuropática, Tópicos, Tratamento.

\section{INTRODUCTION}

First line treatment for neuropathic pain (NP) of different etiologies involves anticonvulsants, antidepressants, opioids and topical analgesics ${ }^{1}$. There are few drugs available for medical prescription and this makes approach and treatment of difficult to control NP a major challenge.

Topical analgesics (TA) are drugs which, when applied to the skin, have local effect and act by modulating peripheral nociceptors ${ }^{2}$. Major advantage of topical agents, as opposed to transdermal agents, is minimal systemic absorption. It is known that oral drugs are associated to possible presence of adverse effects. This often makes unfeasible treatment continuity especially in the elderly or patients with associated diseases.

1. Universidade Federal da Bahia, Salvador, BA, Brasil.

2. Hospital Osvaldo Cruz, Salvador, BA, Brasil.

3. Hospital Santa Isabel, Salvador, BA, Brasil.

Conflict of interests: none - Sponsoring sources: none.

Correspondence to:

Durval Campos Kraychete
Correspondence to:

Rua Rio de São Pedro, 327/401 - Graça

40150-350 Salvador, BA, Brasil.

E-mail: dkt@terra.com.br

(C) Sociedade Brasileira para o Estudo da Dor
Non-steroid anti-inflammatory drugs (NSAIDs), local anesthetics and capsaicin play a slightly better established role in pain control when orally administered, however other drugs have been proposed with variable results. Among them there are tricyclic antidepressants, N-methyl-D-aspartate (NMDA) receptor antagonists and alpha-adrenoreceptor antagonists.

\section{TOPICAL AGENTS}

Anti-inflammatory analgesics

NSAIDs induce analgesia by decreasing production of prostaglandins which sensitize nociceptive nervous fibers at aggression site. This effect is caused by cyclo-oxygenase enzyme inhibition, the expression of which is increased after tissue injury ${ }^{3}$. Topical administration advantage is the decrease of its plasma concentration in $5 \%$ to $15 \%$ as compared to systemic administration ${ }^{4}$, fact which implies higher safety for patients. Authors have evaluated 1 thousand patients in 86 clinical trials and have concluded that NSAIDs are effective to control musculoskeletal pain 5 . There are no studies showing the efficacy of this drug for NP patients.

\section{Capsaicin}

Capsaicin (8-methyl-N-vanillyl-trans-6-nonamide) is active component of chili peppers and highly selective agonist of transient potential vanilloid type 1 receptor. Analgesic effect of capsaicin may be related to depletion of substance $\mathrm{P}$ present in sensory nervous terminations and of epidermal unmyelinated $\mathrm{C}$ fibers morphologic degeneration, with consequent decrease in local innervation. After discontinuing this drug, however, there is nervous fibers regeneration. Capsaicin is associated to extreme discomfort. In addition, it has irritating effect in humans and produces burning sensation associated to local vasodilation ${ }^{6}$.

Topical $0.075 \%$ capsaicin cream should be daily applied, which makes difficult adherence to treatment. So, $0.075 \%$ daily capsaicin for eight weeks may be effective to treat NP with the necessary number to treat (NNT) of $6^{8}$. Alternative, still not available in Brazil, would be $8 \%$ capsaicin patch or 640 $\mu \mathrm{g}$ per $\mathrm{cm}^{2}$, which may be cut to match the region to be treated. This presentation is of exclusive hospital use, and one to four adhesives should be applied to painful area in single dose for a period of 30 to 60 minutes. It should not be used on face, skull or mucosa and skin must have no apparent injury. Due to severe burning sensation produced by capsaicin, it is recommended the use of $4 \%$ lidocaine before placing the patch ${ }^{9,10}$.

A systematic review with meta-analysis ${ }^{11}$ has evaluated topical use of high and low capsaicin concentrations in 1272 patients with postherpetic neuralgia. There has been pain decrease after 8 to 12 weeks of treatment. For high concentrations, NNT was 8.8 and for low concentrations it was 7.0. On the other hand, from two studies with 801 patients with neuropathy induced by human immunodeficiency virus (HIV) it was possible to calculate NNT which was 5.8 for pain intensity decrease. In general, NNT for $30 \%$ to $50 \%$ pain relief, during 2 and 12 weeks, has varied between 10 and 12. Few adverse effects were reported. Authors suggested that best results were obtained with high capsaicin concentrations. So, although controversial, capsaicin might be a therapeutic option for patients intolerant or non-responsive to other first line drugs.

\section{Tricyclic antidepressants}

Tricyclic antidepressants (TAD) are first line drugs ${ }^{1}$ to treat NP and have different action mechanisms. These agents promote norepinephrine and serotonin reuptake inhibition in pre-synaptic level, block NMDA receptors and alpha-2-adrenergic receptors, in addition to acting on sodium, calcium and potassium channels $\mathrm{s}^{12,13}$. Systemic use is associated to urinary retention, dry mouth, sleepiness, constipation, postural hypotension, blurred view and sexual dysfunction, in addition to tachycardia and PR, QRS and QT interval changes with sudden death ${ }^{14}$. It is contraindicated for glaucoma, prostate hy- 
pertrophy and cardiac conduction block patients ${ }^{15}$. In contrast, when TADs are topically applied, the presence of adverse effects is extremely uncommon. Some authors observed that topical preparations containing 3.3\% doxepin or doxepin combined with $0.075 \%$ capsaicin in NP patients may significantly decrease pain as compared to placebo after two weeks of treatment. Action onset was faster with drugs association. There has been increased burning pain in the first week, followed by progressive decrease in the fourth week of treatment. There has been no change in mechanical allodynia, or prickling pain report. However, authors have suggested that the analgesic action might be related to systemic absorption. Adverse effects, such as sleepiness, erythema and itching were minimal and well tolerated ${ }^{16}$.

A recent systematic review with five controlled and two uncontrolled clinical trials has evaluated topical amitriptyline to treat NP of different etiologies. Amitriptyline presentation varied from $1 \%$ to $5 \%$ which was applied to pain site in approximately 4 to $5 \mathrm{~mL}$, three to four times a day. Studies lasted 6 weeks and there has been no significant pain decrease as compared to placebo. Uncontrolled studies have associated $1 \%$ ketamine or $5 \%$ lidocaine and $1 \%$ ketamine to $2 \%$ amitriptyline. In spite of favorable results in decreasing NP, methodological errors, such as lack of comparison group or randomization have given poor clinical relevance to presented data ${ }^{17}$.

\section{$\mathrm{N}$-methyl-D-aspartate receptor antagonists}

Ketamine is a non-competitive NMDA receptors antagonist which decreases neuronal hyperexcitability induced by tissue aggression both in central and peripheral nervous system. Other mechanisms involved in ketamine analgesic action are opioid receptors activation, muscarinic receptors stimulation and changes in voltage-gated calcium channels ${ }^{18}$.

Studies have shown that ketamine has analgesic effect to treat NP by systemic administration; however, its use has been impaired by the presence of adverse effects and lack of oral formulations ${ }^{19}$. Topical ketamine administration is an alternative and some authors advocate its use for believing that ketamine acts on NMDA and peripheral opioids receptors and on sodium and potassium channels block, thus decreasing pain ${ }^{20}$.

Topical $0.5 \%$ to $5 \%$ ketamine, alone or in association with amitriptyline for NP has not significantly decreased pain as compared to placebo. This was shown in different publications including clinical trials and systematic reviews $^{21-24}$. The number of applications has varied from one study to the other and results analyzed between 2 days and 4 weeks were not satisfactory. On the other hand, $10 \%$ concentration, although not decreasing spontaneous pain, may decrease evoked sensory potential 30 minutes after application ${ }^{25}$. More recent studies, however, have shown more positive results of the association of ketamine and amitriptyline (AmiKet) suggesting that clinical efficacy may be associated to the choice of the vehicle, agent concentration, pain site and specific disease ${ }^{26,27}$.

\section{Alfa-2 agonists}

Clonidine is a highly liposoluble alpha-2 agonist, imidazole derivative, historically prescribed as anti-hypertensive agent and with potent antinociceptive action. Clonidine analgesic effects have been attributed to its action in peripheral, spinal and supraspinal regions, with consequent activation of post-synaptic alpha-2 receptors of descending noradrenergic pathways, cholinergic neurons activation and nitric oxide release ${ }^{28}$.

It is known that alpha-2 receptors are metabotropic receptors, bound to intermediate $G$ protein. This protein is formed by three subunits called alpha, beta and gamma. Differences in aminoacids sequence of subunit alpha give origin to protein subtypes responsible for cellular signaling, enzymatic modification and change in ion channels conductance ${ }^{29}$. Systemic clonidine administration is limited by the presence of adverse effects such as sedation, dizziness, nausea, dry mouth, constipation, hypotension and rebound hypertension $^{30}$. On the other hand, the observation of alpha- 2 receptors expression in periphery and high clonidine liposolubility has allowed its topical use for pain treatment. It is possible that clonidine, in activating $G$ protein coupled to alpha-2 receptor, decreases adenylate cyclase enzyme expression, thus decreasing abnormal nociceptors excitability ${ }^{2}$.

Daily use, however, may induce tolerance, which implies the need for increasing doses to reach the same analgesic effect ${ }^{31}$.

Studies have shown that topical $0.1 \%$ gel clonidine has been used in NP patients and may safely and effectively decrease hyperalgesia, especially in individuals with sympathetic-mediated pain and diabetic neuropathy ${ }^{32,33}$. A recent systematic review has found just two controlled studies using topical clonidine to treat NP. Studies' methodology was considered poor. Participated in the studies $344 \mathrm{NP}$ patients who were evaluated during 8 to 12 weeks. There has been no significant decrease when topical clonidine gel was applied 2 to 3 times a day. The necessary number to treat to reach some beneficial effect (NNTB) was $8.33^{34}$.

\section{Local anesthesics}

Local anesthetics (LA) are drugs which, in acting on sodium channels present in cell plasma membrane, reversibly block nervous conduction. This characteristic has allowed the use of LA to promote anesthesia and relieve pain. It is known that calcium channels are multiple and are involved in pain expression. Voltage-gated sodium channels $\mathrm{Na}_{\mathrm{v}} 1.7, \mathrm{Na}_{\mathrm{v}} 1.8$ and $\mathrm{Na}_{\mathrm{v}} 1,9$ play a role in inflammatory pain, while $\mathrm{Na}_{v} 1.3$ on NP and channels $\mathrm{Na}_{v} 1.6$ and $\mathrm{Na}_{v} 1.1$ are still being investigated ${ }^{35}$.

Different topical local anesthetics formulations have been used to treat pain. Among them there are 5\% lidocaine patch (L5P), eutectic mixture of $2.5 \%$ lidocaine- $2.5 \%$ prilocaine (EMLA) and $70 \mathrm{mg}$ lidocaine- $70 \mathrm{mg}$ tetracaine patch (LTP). EMLA and LTP are associated to analgesia and anesthesia, which allows its use in venous puncture, intramuscular injection, lumbar puncture and circumcision ${ }^{36}$. The indication of such agents to treat NP, however, has been questioned, since their benefit was only proven by uncontrolled studies ${ }^{37,38}$.

Lidocaine acts by decreasing voltage-gated sodium channels opening frequency, by blocking depolarization and transmission of nervous fibers action potential, by decreasing both peripheral sensitization and central nervous system hyperexcitability. In low doses, lidocaine inhibits aberrant discharges of focuses generated by nervous injuries, without interfering with normal nervous conduction. So, prolonged treatment with lidocaine topical patch may progressively modulate peripheral neurons hypersensitivity and, consequently, pain $^{39}$

Hydrogel $5 \%$ lidocaine patch of $10 \times 14 \mathrm{~cm}$ is soft and flexible, totaling $700 \mathrm{mg}$ per patch $(50 \mathrm{mg} 5 \%$ lidocaine by water base gram) and a transparent film which should be removed for it to adhere to skin. Major advantage is direct action on pain site, causing less systemic effects, lower toxicity, in addition to not interacting with oral or intravenous drugs. L5P promotes a barrier against mechanical stimuli involved in the allodynia process. There is also no need for titration in the beginning and weaning at the end of treatment ${ }^{40}$. After topical 5\% lidocaine patch application, bioavailability is 3\%, $70 \%$ of what is absorbed are bound to plasma proteins and plasma concentration after patch application is $128 \mathrm{mg} / \mathrm{mL}$. In this concentration, topical analgesia is effective without totally blocking nervous conduction and maintaining skin sensitivity to light touches and pricks. Action onset is 30 minutes after its application, with highest efficacy in 4 hours and action duration of $12 \mathrm{~h}$. In addition, lidocaine serum dosage with maximum dose (3 plasters for $12 \mathrm{~h}$ ) is much lower than the toxic dose of this drug. Lidocaine is metabolized in the liver by cytochromes P450, CYP1A2 and CYP3A4 into the poorly active metabolite monoethyl-glycinexylidide and glycinexylidide. Elimination half life is 7.6 hours, being excreted by kidneys as metabolites or active substance. This half life is slower when there is heart, kidney or liver failure ${ }^{41}$.

L5P is considered first line drug to treat localized NP, although this has been questioned by other authors ${ }^{1}$.

FDA (Food and Drug Administration) has approved the use of L5P in postherpetic neuralgia (PHN) patients, after observation of favorable results in different randomized clinical trials. In such patients, L5P is associated to good tolerance, adequate pain control and improved quality of life ${ }^{44-46}$.

Although L5P is only approved to treat PHN, its advantages have been shown in different pain presentations. A randomized clinical trial with 40 patients diagnosed with localized peripheral painful syndromes, submitted to clinical treatment with $\mathrm{L} 5 \mathrm{P}$ versus placebo during one week has shown significant pain intensity decrease, with NNT of 4.4. Most frequent adverse effect was skin rash ${ }^{47}$.

Other studies with back pain, carpal tunnel syndrome, osteoarthritis and persistent postoperative chronic pain patients have shown lower pain relief ${ }^{48}$. L5P is not approved for pregnant or puerperal women (lidocaine crosses the placenta and is excreted in the milk) or for children (there are still no studies).

Adverse effects are uncommon and include local skin reactions which rapidly improve with plaster discontinuation. Erythema, skin rash, itching, burning sensation, dermatitis and vesicles in application site may occur in $16 \%$. Also, just $5 \%$ of patients with adverse effects need to discontinue treatment. 
Lidocaine plaster improves symptoms such as burning, shock and mechanical allodynia, classic of NP, when used for a long time and does not induce tolerance. Plaster safety profile is very favorable and local tolerability is excellent. Lidocaine patch is contraindicated in patients with hypersensitivity to methylparaben and propylparaben and should also not be applied in areas with solution of continuity or still active injuries ${ }^{49,50}$.

\section{CONCLUSION}

Major NP treatment objective is to decrease pain and improve quality of life of patients. Few studies in the literature validate the use of topical analgesics to treat NP. On the other hand, topical 5\% lidocaine may be safely used, with good efficacy and tolerability. Clinical efficacy of topical analgesics might be associated to the choice of the vehicle, to agent concentration, pain site and specific disease. In this context, new experimental clinical trials should be carried out to validate the use of such agents.

\section{REFERENCES}

1. Finnerup NB, Attal N, Haroutounian S, McNicol E, Baron R, Dworkin RH, et al. Pharmacotherapy for neuropathic pain in adults: a systematic review and meta-analysis. Lancet Neurol. 2015:14(2):162-73

2. Campbell J. A mechanistic approach to the use of topical therapy to treat neuropathic pain. J Peripher Nerv Syst. 2014;19(Suppl 2):S10-1.

3. Vane JR, Bakhle YS, Botting RM. Cyclo-oxygenase 1 and 2. Annu Rev Pharmacol Toxicol. 1998;38:97-120

4. Heyneman CA, Lawless-Liday C, Wall GC. Oral versus topical NSAIDs in rheumatic diseases: a comparison. Drugs. 2000;60(3):555-74.

5. Moore RA, Tramèr MR, Carroll D, Wiffen PJ, McQuay HJ. Quantitative systematic review of topically applied non-steroidal anti-inflammatory drugs. BMJ. 1998;316(7128):333-8. Erratum in: 1998;316(7137):1059.

6. Nolano M, Simone DA, Wendelschafer-Crabb G, Johnson T, Hazen E, Kennedy WR. Topical capsaicin in humans: parallel loss of epidermal nerve fibers and pain sensation. Pain. 1999;81(1-2):135-45.

7. Ellison N, Loprinzi CL, Kugler J, Hatfield AK, Miser A, Sloan JA, et al. Phase III placebo-controlled trial of capsaicin cream in the management of surgical neuropathic pain in cancer patients. J Clin Oncol. 1997;15(8):2974-80.

8. Mason L, Moore RA, Derry S, Edwards JE, McQuay HJ. Systematic review of topical capsaicin for the treatment of chronic pain. BMJ. 2004;328(7446)991

9. Peppin JF, Majors K, Webster LR, Simpson DM, Tobias JK, Vanhove GF. Tolerability of NGX4010, a capsaicin 8\% patch for peripheral neuropathic pain. J Pain Res. 2011:4:385-92.

10. Treede RD, Wagner T, Kern KU, Husstedt IW, Arendt G, Birklein F, et al. Mechanism- and experience-based strategies to optimize treatment response to the capsaicin $8 \%$ cutaneous patch in patients with localized neuropathic pain. Curr Med Res Opin. 2013;29(5):527-38.

11. Derry S, Sven-Rice A, Cole P, Tan T, Moore RA. Topical capsaicin (high concentration) for chronic neuropathic pain in adults. Cochrane Database Syst Rev. 2013;2:CD007393.

12. Acton J, McKenna JE, Melzack R. Amitriptyline produces analgesia in the formalin pain test. Exp Neurol. 1992;117(1):94-6.

13. Michelson D, Misiewicz-Poltorak B, Raybourne RB, Gold PW, Sternberg EM. Imipramine reduces the local inflammatory response to carrageenin. Agents Actions. 1994;42(1-2):25-8

14. Attal N, Bouhassira D. Pharmacotherapy of neuropathic pain: which drugs, which treatment algorithms? Pain. 2015;156(Suppl 1):S104-14.

15. Godfrey RG. A guide to the understanding and use of tricyclic antidepressants in the overall management of fibromyalgia and other chronic pain syndromes. Arch Intern Med. 1996;156(10):1047-52.

16. McCleane G. Topical application of doxepin hydrochloride, capsaicin and a combination of both produces analgesia in chronic human neuropathic pain: a randomized, double-blind, placebo-controlled study. Br J Clin Pharmacol. 2000;49(6):574-9.

17. Thompson DF, Brooks KG. Systematic review of topical amitriptyline for the treatment of neuropathic pain. J Clin Pharm Ther. 2015;7 [Epub ahead of print).

18. Hustveit $\mathrm{O}$, Maurset A, Oye I. Interaction of the chiral forms of ketamine with opioid, phencyclidine, sigma and muscarinic receptors. Pharmacol Toxicol. 1995;77(6):355-9.

19. Radvansky BM, Puri S, Sifonios AN, Eloy JD, Le V. Ketamine-a narrative review of its uses in medicine. Am J Ther. 2015;24. [Epub ahead of print].

20. Gammaitoni A, Gallagher RM, Welz-Bosna M. Topical ketamine gel: possible role in treating neuropathic pain. Pain Med. 2000;1(1):97-100.
21. Lynch ME, Clark AJ, Sawynok J, Sullivan MJ. Topical $2 \%$ amitriptyline and $1 \%$ ketamine in neuropathic pain syndromes: a randomized, double-blind, placebo-controlled trial. Anesthesiology 2005;103(1):140-6.

22. Gewandter JS, Mohile SG, Heckler CE, Ryan JL, Kirshner JJ, Flynn PJ, et al. A phase III randomized, placebo-controlled study of topical amitriptyline and ketamine for chemotherapy-induced peripheral neuropathy (CIPN): a University of Rochester CCOP study of 462 cancer survivors. Support Care Cancer. 2014;22(7):1807-14

23. Mahoney JM, Vardaxis V, Moore JL, Hall AM, Haffner KE, Peterson MC. Topical ketamine cream in the treatment of painful diabetic neuropathy: a randomized, placebo-controlled, double-blind initial study. J Am Podiatr Med Assoc. 2012;102(3):178-83.

24. Kopsky DJ, Keppel Hesselink JM, Bhaskar A, Hariton G, Romanenko V, et al. Analgesic effects of topical ketamine. Minerva Anestesiol. $2015 ; 81(4): 440-9$.

25. Sawynok J. Topical and peripheral ketamine as an analgesic. Anesth Analg. 2014;119(1):170-8.

26. Sawynok J, Zinger C. Topical amitriptyline and ketamine for post-herpetic neuralgia and other forms of neuropathic pain. Expert Opin Pharmacother. 2016;17(4):601-9.

27. Mercadante S. Topical amitriptyline and ketamine for the treatment of neuropathic pain. Expert Rev Neurother. 2015;15(11):1249-53

28. Eisenach J, Detweiler D, Hood D. Hemodynamic and analgesic actions of epidurally administered clonidine. Anesthesiology. 1993;78(2):277-87.

29. Casey PJ, Gilman AG. G protein involvement in receptor-effector coupling. J Biol Chem 1988;263(6):2577-80.

30. Ghoshmaulik S, Bisui B, Saha D, Swaika S, Ghosh AK. Clonidine as an adjuvant in axillary brachia plexus block for below elbow orthopedic surgeries: A comparison between local and systemic administration. Anesth Essays Res. 2012;6(2):184-8.

31. Dogrul A, Uzbay IT. Topical clonidine antinociception. Pain. 2004;111(3):385-91

32. Davis KD, Treede RD, Raja SN, Meyer RA, Campbell JN. Topical application of clonidine relieves hyperalgesia in patients with sympathetically maintained pain. Pain. 1991;47(3):309-17.

33. Campbell CM, Kipnes MS, Stouch BC, Brady KL, Kelly M, Schmidt WK, et al. Randomized contro trial of topical clonidine for treatment of painful diabetic neuropathy. Pain. 2012;153(9):1815-23.

34. Wrzosek A, Woron J, Dobrogowski J, Jakowicka-Wordliczek J, Wordliczek J. Topical clonidine for neuropathic pain. Cochrane Database Syst Rev. 201531;8:CD010967.

35. Eijkelkamp N, Linley JE, Baker MD, Minett MS, Cregg R, Werdehausen R, et al. Neurological perspectives on voltage-gated sodium channels. Brain. 2012;135(Pt 9):2585-612.

36. Galer BS. Topical Medications. In: Loeser JD, editor. Bonica's Management of Pain. Philadelphia Lippincott-Williams and Wilkins; 2001. 1736-41p.

37. Attal N, Brasseur L, Chauvin M, Bouhassira D. Effects of single and repeated applications of a eutectic mixture of local anesthetics (EMLA) cream on spontaneous and evoked pain in post-herpetic neuralgia. Pain. 1999:81(1-2):203-9.

38. Litman SJ, Vitkun SA, Poppers PJ. Use of EMLA cream in the treatment of post-herpetic neuralgia. J Clin Anesth. 1996;8(1):54-7.

39. Lai J, Porreca F, Hunter JC, Gold MS. Voltage-gated sodium channels and hyperalgesia. Annu Rev Pharmacol Toxicol. 2004;44:371-97.

40. Davies PS, Galer BS. Review of lidocaine patch 5\% studies in the treatment of postherpetic neuralgia. Drugs. 2004;64(9):937-47.

41. Gammaitoni AR, Davis MW. Pharmacokinetics and tolerability of lidocaine patch $5 \%$ with extended dosing. Ann Pharmacother. 2002;36(2):236-40.

42. Dworkin RH, O'Connor AB, Backonja M, Farrar JT, Finnerup NB, Jensen TS, et al. Pharmacologic management of neuropathic pain: evidence-based recommendations. Pain. 2007;132(3):237-51

43. Gilron I, Baron R, Jensen T. Neuropathic pain: principles of diagnosis and treatment. Mayo Clin Proc. 2015;90(4):532-45.

44. Rowbotham MC, Davies PS, Verkempinck C, Galer BS. Lidocaine patch: double-blind controlled study of a new treatment method for post-herpetic neuralgia. Pain 1996;65(1):39-44.

45. Galer BS, Rowbotham MC, Perander J, Friedman E. Topical lidocaine patch relieves post-herpetic neuralgia more effectively than vehicle patch: results of an enriched enrolment study. Pain. 1999;80(3):533-8.

46. Katz NP, Davis MW, Dworkin RH. Topical lidocaine patch produces a significant improvement in mean pain scores and pain relief in treated PHN patients: results of a multicenter open-label trial. Pain. 2001;2(1):9-18.

47. Meier T, Wasner G, Faust M, Kuntzer T, Ochsner F, Hueppe M, et al. Efficacy of lidocaine patch $5 \%$ in the treatment of focal peripheral neuropathic pain syndromes: a randomized, double-blind, placebo-controlled study. Pain. 2003;106(1e2):151-8.

48. de León-Casasola OA, Mayoral V. The topical $5 \%$ lidocaine medicated plaster in localized neuropathic pain: a reappraisal of the clinical evidence. J Pain Res. 2016;9(1):67-79

49. Dakin H, Nuijten M, Liedgens H, Nautrup BP. Cost-effectiveness of a lidocaine $5 \%$ medicated plaster relative to gabapentin for postherpetic neuralgia in the United Kingdom. Clin Ther 2007:29(7):1491-507.

50. Liedgens H, Hertel N, Gabriel A, Nuijten M, Dakin H, Mitchell S, et al. Cost-effectiveness analysi of a lidocaine $5 \%$ medicated plaster compared with gabapentin and pregabalin for treating postherpetic neuralgia: a German perspective. Clin Drug Investig. 2008;28(9):583-601. 